\title{
Public opinion in the site selection process: survey methodologies
}

\author{
Sebastian Götte ${ }^{1}$, Roman Seidl ${ }^{2}$, Ariane Breyer ${ }^{3}$, and Zoë Felder ${ }^{3}$ \\ ${ }^{1}$ aproxima Gesellschaft für Markt- und Sozialforschung Weimar mbH, Weimar, Germany \\ ${ }^{2}$ Institute of Radioecology and Radiation Protection, Leibniz University Hannover, Hanover, Germany \\ ${ }^{3}$ Federal Office for the Safety of Nuclear Waste Management (BASE), Berlin, Germany
}

Correspondence: Zoë Felder (zoe.felder@bfe.bund.de)

Published: 10 November 2021

\begin{abstract}
The aim of the site selection process (StandAV) is to find the repository site for high-level radioactive waste with the best possible safety. Transparency and public involvement contribute to ensuring that the outcome of the site selection process is "supported by a broad consensus in society and can thus also be tolerated by those affected" (StandAG $§ 5$ para. 1). In order for the public to be suitably informed and involved, BASE (Federal Office for the Safety of Nuclear Waste Management), in particular, as the body responsible for public participation, must base its work on the knowledge, attitudes and needs of the German population.

In order to gain the respective knowledge, the company aproxima Gesellschaft für Markt- und Sozialforschung Weimar $\mathrm{mbH}$ was commissioned to conduct a repetitive representative survey (research project EWident). The study briefly deals with nuclear energy in general, but mainly focuses on questions related to the topic of final disposal (knowledge of the topic and especially the StandAV, interest in information and involvement, relevance of particular questions in the process, etc.). The first survey took place in summer 2020. A special focus was placed on the younger generation (14- to 29-year-olds). The results can be viewed on the BASE website (Götte and Ludewig, 2020). They show that the level of knowledge about and interest in StandAV are still rather feeble; at the same time, it is clear that questions of safety are a central driver for accepting a possible site in one's own region. A second survey is planned for autumn 2021.

A comparably broadly drawn survey has not been carried out in recent years. However, the fact that the topic of final disposal is becoming increasingly important is shown by thematically related surveys that ask about attitudes towards nuclear energy or examine particular aspects of StandAV in more detail. Within the framework of the TRANSENS research association (Transdisciplinary Research on the Management of HighLevel Radioactive Waste in Germany), for example, trust and confidence in the context of the site selection process were surveyed.
\end{abstract}

The 60 min workshop is aimed at interested parties and researchers who would like to contribute their own experiences with related surveys. In the workshop we provide three incentives.

1. aproxima introduces the methods and key results of EWident's first survey.

2. BASE gives an insight into the practical use of these results.

3. Roman Seidl of Leibniz University Hannover reports the results of the TRANSENS survey.

Subsequently, we would like to discuss the following questions, among others, with the participants in the workshop. What is remarkable about the results? Do they differ from other StandAV surveys and experiences, and if so, how? How can this be explained? What further research needs can be identified? With what approaches could they be met?

Kurzfassung. Ziel des Standortauswahlverfahrens (StandAV) ist es, den Endlagerstandort für hochradioaktive Abfälle mit der bestmöglichen Sicherheit zu finden. Durch Transparenz und den Einbezug der Öffentlichkeit soll zudem erreicht werden, dass das Ergebnis des StandAV „in einem breiten gesellschaftlichen Konsens getragen 
wird und damit auch von den Betroffenen toleriert werden kann“"(StandAG § 5 Abs. 1). Damit die Öffentlichkeit passend informiert und beteiligt werden kann, muss insbesondere das BASE (Bundesamt für die Sicherheit der nuklearen Entsorgung) als Träger der Öffentlichkeitsbeteiligung Kenntnisse über Wissen, Einstellungen und Bedarfe in der bundesdeutschen Bevölkerung zugrunde legen.

Um diese Kenntnisse zu erlangen, wurde die aproxima Gesellschaft für Markt- und Sozialforschung Weimar mbH mit der Durchführung einer wiederholten repräsentativen Bevölkerungserhebung beauftragt (Forschungsprojekt EWident). Die Studie thematisiert knapp Kernenergie allgemein, fokussiert im Wesentlichen aber Fragen rund um das Thema Endlagerung (Kenntnisse zur Thematik und speziell dem StandAV, Interesse an Information und Beteiligung, Relevanz einzelner Fragestellungen im Verfahren usw.). Die erste Erhebung fand im Sommer 2020 statt. Ein besonderer Fokus lag dabei auf der jungen Generation (14- bis 29-Jährige). Die Ergebnisse können auf der BASE-Webseite eingesehen werden (Götte und Ludewig, 2020). Sie zeigen, dass der Kenntnisstand über und das Interesse am StandAV noch eher schwach ausgeprägt sind; zugleich wird deutlich, dass Fragen der Sicherheit einen zentralen Treiber für die Akzeptanz eines möglichen Standorts in der eigenen Region darstellen. Eine zweite Erhebung ist für Herbst 2021 geplant.

Eine vergleichbar breit angelegte Erhebung wurde in den letzten Jahren nicht durchgeführt. Dass das Thema Endlagerung aber immer mehr an Bedeutung gewinnt, zeigen thematisch verwandte Erhebungen, die beispielsweise Einstellungen zur Kernenergie abfragen oder einzelne Aspekte des StandAV näher untersuchen. Im Rahmen des Forschungsverbunds TRANSENS (Transdisziplinäre Forschung zur Entsorgung hochradioaktiver Abfälle in Deutschland) etwa wurde das Vertrauen in die Institutionen der Endlagersuche erhoben.

Der 60-minütige Workshop richtet sich an Interessierte und Forscher*innen, die eigene Erfahrungen mit verwandten Erhebungen einbringen möchten. In dem Workshop geben wir 3 Impulse:

1. aproxima stellt Methodik und zentrale Ergebnisse der ersten Erhebung von EWident vor.

2. Das BASE gibt einen Einblick in die praktische Nutzung dieser Ergebnisse.

3. Roman Seidl von der Leibniz Universität Hannover berichtet Ergebnisse der Erhebung im Rahmen von TRANSENS.

Mit den Teilnehmer*innen des Workshops möchten wir anschließend u. a. folgende Fragen diskutieren: Was ist auffällig an den Ergebnissen? Wo weichen sie ggf. von anderen Erhebungen und Erfahrungen im Rahmen des StandAV ab und wodurch kann dies erklärt werden? Welcher weitere Forschungsbedarf kann identifiziert werden? Mit welchen Ansätzen könnte dieser gedeckt werden?

\section{References}

Götte, S. and Ludewig, Y.: Endlagersuche in Deutschland: Wissen, Einstellungen und Bedarfe - wiederholte repräsentative Erhebung (EWident), Zwischenbericht zur ersten Bevölkerungsbefragung im Jahr 2020, Forschungsvorhaben im Auftrag des BASE (FKZ 4719F00201), https://www.base.bund.de/DE/themen/fa/ sozio/projekte-aktuell/projekte-aktuell.html (last access: 28 October 2021), 2020. 